\title{
Using Simulations in Teaching Research Academic Writing Course
}

\begin{abstract}
The article focuses on teaching research academic writing to undergraduates taking a Russian-American dualdegree program offered by Baikal International Business School and its partner University of Maryland Global Campus. As the American program is online, writing courses are mandatory. Being the final course in the writing module, research academic writing is challenging not only for students but also for the instructor. This makes the teacher look for new ways to improve the quality of teaching and to motivate undergraduates. The paper describes action research aiming at introducing simulation games in research academic writing course to engage students in classroom activities, vary practical assignments, and make classes more interactive. Using observation, student questionnaires and interviews, the author compares her class atmosphere and student involvement before and after the intervention. As a result of her research, the author comes to the conclusion that simulation activities, besides other advantages, can be successfully used for teaching academic writing since they increase motivation and student engagement creating a positive learning environment. Moreover, pair or group work can minimize difficulties, which helps to better understand the material. Furthermore, simulation activities have a practical value enabling students to develop skills and competences vital for future managers. Also the paper offers simulation activities developed for the course which are given in the appendices. Key words: teaching, research academic writing, action research, simulation activities.

Citation. Luganskaya Ye.V. Using Simulations in Teaching Research Academic Writing Course. Vestnik Samarskogo universiteta. Istoriia, pedagogika, filologiia = Vestnik of Samara University. History, pedagogics, philology, 2020, vol. 26, no. 4, pp. 68-75. DOI: http://doi.org/10.18287/2542-0445-2020-26-4-68-75. (In Russ.)

Information on the conflict of interests: author declares no conflict of interest.

(C) Yevgeniya V. Luganskaya - Candidate of Philological Sciences, Master of Management, associate professor, Humanities and Foreign Languages Department, Siberian-American School of Management, Baikal International Business School, Irkutsk State University, 1, Karl Marx Street, Irkutsk, 664003, Russian Federation.
\end{abstract}

\section{НАУЧНАЯ СТАТЬЯ}

УДК 378:802

Дата поступления: 16.09.2020 рецензирования: 24.11 .2020 принятия: 27.11 .2020

Е.В. Луганская

Иркутский государственный университет, Иркутск, Российская Федерация E-mail: lug-evgenia@mail.ru. ORCID: https://orcid.org/0000-0003-1218-2457

\section{Использование симулятивных игр в обучении письму для исследовательских целей} Аннотация: В статье автор рассматривает проблему преподавания курса академического письма для
исследовательских целей на примере обучения студентов по двойной русско-американской программе
бакалавриата, осуществляемой Байкальской международной бизнес-школой и Мерилендским университетом.
Так как обучение по американской программе проводится дистанционо, курсы по письму обязательны.
Являясь финальной дисциплиной при обучении письму, академическое письмо для исследовательских целей
представляет наибольшую трудность как для студентов, так и для преподавателя, что заставляет искать новые
методики обучения для улучшения качества преподавания, а также повышения мотивации студентов. В статье
описывается опыт проведения экспериментального мини-исследования, состоящего во внедрении симулятивных
игр в процесс обучения письму для того, чтобы разнообразить практические задания и сделать устные занятия
более интерактивными и увлекательными. С помощью методов наблюдения, анкетирования и интервью среди
студентов сравнивается ситуация до и после использования симулятивных упражнений. В результате мини-
исследования автор приходит к выводу, что симулятивные игры, помимо других преимуществ, могут быть
успешно использованы при обучении письму и значительно повышают мотивацию и вовлеченность студентов
в учебный процесс, что создает позитивную атмосферу во время занятий. Кроме того, работа в паре или группе
при выполнении заданий данного типа снимает трудность, тем самым помогая лучше воспринимать учебный
материал, а практическая направленность симулятивного обучения позволяет в игровой форме развивать
необходимые навыки и компетенции. Для эксперимента автором разработаны симулятивные задания, которые
приводятся в приложениях.
Ключевые слова: преподавание, академическое письмо для исследовательских целей, экспериментальное исследование, симулятивные игры. 
Цитирование. Луганская Е.В. Использование симулятивных игр в обучении письму для исследовательских целей // Вестник Самарского университета. История, педагогика, филология. 2020. Т. 26, № 4. C. 68-75. DOI: http://doi.org/10/12287/2542-0445-2020-26-4-68-75.

Информация о конфликте интересов: автор заявляет об отсутствии конфликта интересов.

(C) Евгения Валерьевна Луганская - кандидат филологических наук, магистр менеджмента, доцент Сибирско-американского факультета менеджмента, кафедра гуманитарных дисциплин и иностранных языков, Байкальская международная бизнесшкола, Иркутский государственный университет, 664003, Российская Федерация, г. Иркутск, ул. Карла Маркса, 1.

\section{Introduction}

Teaching writing at universities is one of the most urgent issues of teaching English nowadays. Good English writing skills are essential for Russian students as they enable them to participate in different programs abroad, apply for grants, and study in foreign universities and colleges. They give them a chance to rise to international standards and work in international companies and institutions. As Hyland states, "writing in the academy has assumed huge importance in recent years as countless students and academics around the world must now gain fluency in the conventions of academic writing in English to understand their disciplines, to establish their careers or to successfully navigate their learning" [Hyland 2013, p. 2]. However, writing in English for non-natives is difficult both to teach and to learn, especially when it comes to research and academic writing.

At Baikal International Business School, taking a writing course is a must for those students who passed TOEFL and enrolled in the American program that Irkutsk State University and the Universityof Maryland Global Campus offer. This is a joint program in which the students will get dual certificates from the two universities. These students major in management and are expected to take 10 courses on Management online offered by the partner college. In addition to these courses, the requirement of the American university is that the students take three writing courses (Introduction to Writing, Critical Thinking and Academic Writing, and Research Academic Writing course (RAW)) delivered by Russian professors. These courses are extremely important for them as the students have to interact with their American instructors in English and submit all the assignments in writing. The RAW class meets twice per week and includes lectures and seminars (one lecture and one seminar per week); the audience is sophomores, juniors, and seniors aged 19-21.

Even though this course is delivered for the third time, there are a lot of challenges the instructor faces, one of which is adapting the high requirements of the course to the needs and abilities of the students. The problem is that the English language proficiency of the students varies from advanced to intermediate; all of them passed TOEFL pbt and had not taken writing before the American program. In spite of the fact that RAW is the final course in the writing module, writing is still very difficult for undergraduates. Not only is it hard for them to do writing assignments but they are also noisy or inattentive in class during the lectures and seminars. So the students show a low motivation although they understand that writing is important for them. The professors who conducted the two writing prerequisite courses had similar problems with the students.

The action research project aims at increasing motivation and engagement of the students in class work. To solve the problem, different methods were used. For example, the group work was not very effective as the students were only pretending to be doing the task, continuing to discuss their own problems with each other. So the teacher had to come up with something that might show them how useful and down-to-earth the course was, and simulations were chosen as an experiment.

The research question is how the use of simulated activities will affect the students' motivation during the course. The purpose of this study is to understand how to organize classroom work during RAW so that (1) it might be interesting and appealing to students; (2) it could increase their awareness of the importance of the course and its practical application; (3) it might build confidence and help them overcome challenges. Another reason for undertaking this project is that there were a lot of complaints at the department from the colleagues, who deliver the other two prerequisite courses, concerning the students' lack of writing skills, interest, and low motivation. Therefore, it is necessary to find a way to organize the writing module in a livelier manner, making it more practiceoriented.

\section{Literature Review}

The idea of using simulation in education is not new: it has been around for more than half a century already [Ruben 1999]. Born in the 1960s thanks to the emergence of the experiential instruction theory and communicative methodology, it has not only withstood the test of time, significantly influencing classroom instruction, but also gained increasing popularity due to its benefits and, perhaps, the increased availability of technology-based tools that can support simulation [Ke 2008; Ranalli 2008; Rieber 2005]. The use of simulation in the classroom is based on several assumptions: learning should be active ("learning by doing"), learning environments need to be learner centered, and knowledge should be translated into behavior. Simulation games and role plays, as well as some other forms of interactive 
learning, help to put the above mentioned principles into practice.

Nowadays the use of simulated activities is widely recognized as an important tool for teaching English as these activities can enrich teaching and learning [Balasubramanian, Wilson 2005]; enable students to learn and experience real-life situations [DeBord 1989]; encourage thinking and creativity; let students develop and practice new language and behavioral skills in a relatively nonthreatening setting; and can create the motivation and involvement necessary for learning to occur [Tompkins 1998]. Moreover, simulations are good for developing oral communicative skills. For example, the study by Javid revealed a reasonable progress in the students' oral communication proficiency and improvements in their listening skills [Javid 2013]. Another benefit is that simulation is a problem-solving activity to which the students bring their own peculiar personalities, distinct experiences and opinions [Livingstone 1983]. In addition, simulation introduces a variety of ways to make the whole language learning process more interesting, challenging and lively. The researcher believes that simulation motivates learners because it takes place in a stress-free situation and injects a feeling of realism and relevance into the classroom, which makes the language learning process more exciting as teachers move away from just using textbooks or written materials for language practice. Despite a lot of benefits, some sources mention minor disadvantages: simulations are time consuming and put demands on both students and teachers (in terms of preparation and selection). As we see, the research on the use of simulations is extensive and focuses on a wide range of topics from their benefits and procedure [Ellington, Gordon, Fowlie 2013; Harry 1969; Jones 1989] to assessment via simulations and role plays [Barry, Trapp 2013].

Regarding the definition of the term simulation, a lot of researchers define it similarly. Adams, for example, claims that a simulation is a controlled detailed mode intended to reflect a situation from the real world to learn about real experiences [Adams 1973]. As it follows from the definition, the focus here is on a practical approach to learning: engaging students in real-life situations. According to Russell \& Shepherd [Russell, Shepherd 2010], simulations are a form of experiential learning like role plays. Again the authors emphasize the same idea of "learning by doing".

Although researchers seem to agree on the definition of simulation, they are not so unanimous when it comes to defining the related terms simulation, game, simulation game, and role play which are often discussed together. Sometimes simulation and role play are used interchangeably [Tompkins, 1998], but more often a simulation is considered to be a broader concept than role play and includes the latter [Barry, Trapp 2013], while a game, unlike simulations and role plays, has well-defined goals and objectives involving winners or losers and a sense of competition [Sutcliffe 2002]. A simulation game is "a structured, preplanned activity designed to stimulate the real world that has rules, scoring, and defined procedures. This activity combines the characteristics of games (a scored contest in which people abide by a set of rules) and simulation (an imitation or simplification of some aspect of reality)" [Crow 2008].

To avoid ambiguity, in the paper simulation will refer to a teaching technique which allows students to work at a certain task or solve a certain problem, relevant to the lives and interests of students, in a group setting according to the planned scenario. It gives them a chance to apply their knowledge and experience to real-life situations making their own choices and decisions. Role plays also fall into this category.

A lot of researchers and educators report about the successful use of simulated activities in different disciplines varying from economics [Sutcliffe 2002] to sciences [Honey, Hilton 2011]. However, no studies to date deal with the use of this method in teaching RAW. So it will be interesting to see how simulated activities are applicable to the RAW course and whether this approach will help motivate the students. The assumption is that simulations and role plays might show the students how the RAW course relates to real-life situations and their interests offering them an alternative teaching format instead of traditional lectures and seminars.

\section{Methods}

To understand if simulated activities are helpful, both observable and non-observable data were collected. To ensure triangulation, data from two sources (the students and the observer - myself) were combined with different methods of data collection. The observable data were the observer's reflective notes about classroom activities and the students' reactions during the traditional lecture and seminar format and during simulations and role plays. Making more structured observations turned out impossible as it was difficult to deliver a class and make detailed notes at the same time. As for reflective notes, they proved to be easier to manage as they were made during some class breaks while the students were engaged in reading or participating in simulations. Some segments of classroom work were audio-recorded, which helped to add more reflections later to the observations made during the class.

Other methods that that were used were nonobservable: student questionnaires and interviews. All in all the students filled out 3 surveys. The first one was conducted before the course and focused 
on the students' attitudes to writing, their problems with writing, and possible ways of tackling these problems. The second one was administered when the course was underway but before simulations were incorporated, which helped to understand what forms of work the students found useful during usual lectures and seminars. The last questionnaire was used at the end of the course to assess what changed after the intervention.

Furthermore, to get some qualitative data, semi-structured interviews with the students were conducted, which enabled both to make some kind of comparison across the participants' responses and to allow for individual diversity and flexibility [Burns 2010, p. 75].

\section{Results and Discussion}

The observable data show that there is a considerable difference in the behavior of the students during the traditional lecture and seminar format and when they were engaged in simulated activities. During the usual lectures and seminars, it was difficult for the students to hold their attention for more than 40-50 min in a row (a class lasts 90 $\mathrm{min}$ ) even though the instructor tried to make classes interesting and interactive, including group work or pair work, different cartoons related to research or incorporating catchy quotes and videos. The audience chatted with each other from time to time, used their phones or laptops, did other assignments, or even slept. The instructor had to raise her voice once to make them quiet as it was too noisy and only few people were listening. There was frustration in the beginning, and all attempts to motivate the audience and make them more attentive were almost fruitless. The only thing the teacher managed to succeed in was that one-third of the students who were interested from the very beginning and always listened were engaged even more. Probably, it was their attention and efforts that made the teacher (i. e. me) keep trying. When the students heard the teacher raise her voice, some of them were surprised because they could not understand the reaction. They explained that it was their usual behavior during lectures and that there was nothing wrong with the RAW lectures. Those who slept said that all lectures were for sleeping only adding, "There's nothing else to do during lectures". One student kept sighing loudly asking her fellow students, "What for do we need all this?" addressing this question to her fellow students but making sure the teacher heard it. The situation did not change much when the students got acquainted with the syllabus which demonstrated that the topics they were supposed to focus on would be their writing assignments that would be graded and that those assignments would make up their final paper, which was worth almost $30 \%$ of the final grade for the course. Later, one of the students explained that they did all the assignments at the very last moment because they could not physically do them earlier but the lectures were given at least a week before a certain assignment was due, and it was not important for them yet as they had lots of other things to consider first. She commented that they had to live from deadline to deadline. It was clear that they were very busy as the American program they were taking did not free them from the requirements and assignments of the Russian program, but this did not explain why the audience was inattentive during RAW classes.

So it was a challenge for the instructor to change the attitude. Probably, it was not the students' heavy load or bad manners that were to blame but rather lack of understanding how the course meets their needs and is applicable to their studies and real life. As a result, to show how the RAW course relates to real-life situations and interests of students, different simulated activities were introduced to help the students conduct their research and write their final research papers. The simulated activities included the following: selecting the abstracts for publishing articles by the publishing board, conducting questionnaires, interviewing people, handling a focus group discussion, doing research in class, and moderating mini-conferences. After the intervention, the students' behavior changed for the better during the simulations. They were excited, enthusiastic about their assignments and eager to finish them first. However, by the time simulations were incorporated into traditional lectures and seminars, four students had stopped coming to RAW classes and seven other students came irregularly. Those who were present did well during all the simulations, putting into practice the knowledge they gained in class and experience they had.

As for the conducted surveys, the first one showed that $90 \%$ of respondents consider academic writing very important and $10 \%$ somewhat important, even though almost all of them (95\%) are interested more in business writing. Taking into account these data, their classroom behavior seemed inconsistent. The second and the third questionnaires dealt mostly with different forms of work in mastering academic writing. The results are presented in Figure.

As we can see, there are some changes before and after the intervention: the students reconsidered their attitude to simulated activities and found them useful ( $13 \%$ vs $73 \%)$. In the beginning the term group work was used instead as the students did not know what simulated activities were. Also the students changed their attitude to exercises: later in the course they believed they were less beneficial ( $35 \%$ vs $51 \%$ ). Probably, the questionnaires should have been more focused on simulated activities, but the research question was changed several times as different methods and activities were introduced during lectures and seminars in order to understand what worked better. 


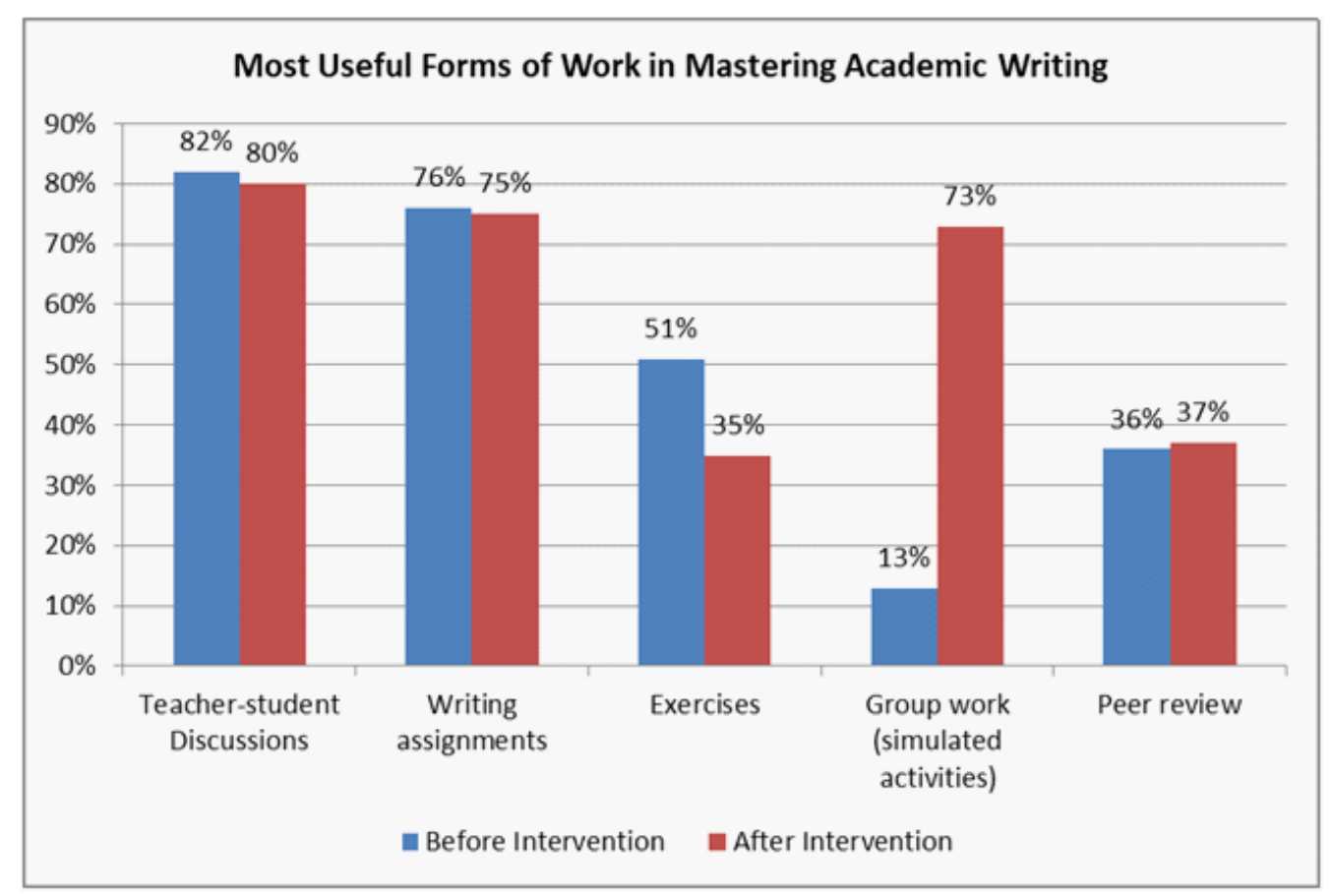

Fig. Most useful Forms of Work in Mastering Academic Writing

The four interviews with the students elaborated on their answers to the survey questions (whether they liked simulations and why or why not, which one(s) they liked more and why, whether they had any difficulties participating in them, why they misbehaved during the lectures in the beginning and what they thought about the course) and showed that all of them liked simulations though one of the students said it was fun not only to try their hand at researching but also to collect the data outside the class while other groups were studying. The simulation they liked most was conducting a research on their own when they had to decide and plan everything themselves.

When asked why they thought in the beginning that group work was not useful, they explained that they did not understand how the students themselves could solve research problems as they lacked knowledge and expertise. But they turned out to have enough experience to complete their simulations. They also mentioned that they appreciated the alternative teaching format more than traditional lectures and seminars. Perhaps, it was just hard for them to listen to lectures in English as they were not used to that. All in all, the experiment proved successful, even though not all the students participated in simulations and filled out the questionnaires. Those who did were glad that they had tried simulated activities and wished they "had done them all the time" instead of studying theory. Also the undergraduates mentioned they had to improve communication skills to settle the differences during decision-making.

For more objectivity, perhaps, it would have been good to invite a colleague to observe RAW classes but there are few people at the department and the classes are taught simultaneously. In the end of the course, the head of the department (the professor who conducts Introduction to writing course) came to observe our mini-conference where the student acted as a moderator and the chair admitted that the students were much more motivated when they presented their final papers and discussed them than when they were exposed to a teacher-student format of traditional lectures and seminars.

Obviously, there may be other reasons why the attitude has changed. The students might have just gotten used to the requirements and delivery and better understood the topics as the course progressed. Another possible reason is that the students were doing research in other subjects and they knew that they might use that research to write a research paper for RAW. So they felt more motivated and interested as they saw how RAW course might come in handy. One more reason may be that the course was coming to an end, and they wanted to get better grades.

\section{Conclusion and Reflections}

Even though after the research it is not absolutely clear that it was simulation that motivated the students, there is certainty that simulated activities are a powerful tool for learning and experiencing real life situations, problem solving, and making classes more interesting and livelier. So the research findings can add one more area - RAW where simulations proved beneficial - to other different disciplines where simulations were successfully used. Moreover, pair or group work during simulations minimized difficulties, which helped to better understand the material. Furthermore, simulation activities have a 
practical value enabling students to develop skills and competences important for managers.

Looking for ways to increase the students' motivation helped to find interesting materials: catchy quotes and cartoons, videos that showed some common research mistakes, interesting articles on the subjects that the class focuses on and the students choose for their research papers. Also the undertaken action research encouraged the teacher to think of other simulated activities and role plays which could have been used earlier, but the ideas occurred late. So next time it will be easier to teach this course.

Another benefit of the action research is that the project made the teacher reflect a lot onthe manner of teaching. Probably it was too academic in the beginning. Even though some lectures and seminars that had been conducted before proved very successful with the different audiences (students of the linguistic university and master's degree students), this class did not respond well to the RAW course in the beginning. That is why the manner of delivering the material, the topics taught during lectures or seminars as well as activities had to be changed more often. Looking for the way to make the students listen to the teacher, the teacher learned to listen to the students better. Having experienced a whole range of feelings throughout this course from frustration and anger to pride for the students, when they defended their projects in front of the head of the department, the author is satisfied with the progress and achievements of most of the students who submitted their final papers. Now the next logical step will be designing new activities to improve writing skills.

\section{References / Библиографический список}

Adams 1973 - Adams D.M. (1973) Simulation games: an approach to learning. Ohio: Charles A. Jones, 120 p. Available at: https://archive.org/details/simulationgamesa0000adam.

Balasubramanian, Wilson 2005 - Balasubramanian $N$. and Wilson B.G. (2005) Games and simulations. Available at: https://www.researchgate.net/profile/ Brent_Wilson3/publication/228979011_Games_and simulations/links/0c96051703f63958ea000000/Gamesand-simulations.pdf?origin=publication_detail.

Barry, Trapp 2013 - Barry B. and Trapp G. (2013) Assessing with role play and simulation. Available at: https://teaching. unsw.edu.au/assessing-role-play-and-simulation.

Burns 2010 - Burns A. (2010) Doing action research in English language teaching: a guide for practitioners. New York and London: Routledge, 196 p. DOI: http://doi. org/10.4324/9780203863466.

Crow 2008 - Crow M. (2008) Simulation games and role play. Available at: https://ru.scribd.com/document/ 140081847/Simulations-Games-and-Role-Play.

DeBord 1989 - DeBord K. (1989) Creative teaching: simulations, games, and role playing. Journal of Extension, vol. 27, no. 2. Available at: http://www.joe.org/ joe/1989summer/tt1.php.
Ellington, Gordon, Fowlie 2013 - Ellington H., Gordon M. and Fowlie J. (2013) Using Games and Simulations in the Classroom: a practical guide for teachers. London, England: Routledge, 224 p. DOI: http://doi. org/10.4324/9780203770955.

Harry 1969 - Harry L. (1969) Using simulation games in the classroom. Report Number 44. Available at: http://files. eric.ed.gov/fulltext/ED031767.pdf.

Honey, Hilton 2011 - Honey M. and Hilton M.L. (Eds.) (2011). Learning science through computer games and simulations. Washington, DC: The National Academies Press, 174 p. Available at: https://b-ok.global/ book/873267/577ead.

Hyland 2013 - Hyland K. (2013) Writing in the university: education, knowledge and reputation. Language Teaching, no. 46 (1), pp. 53-70. DOI: http://doi.org/10.1017/ S0261444811000036.

Javid 2013 - Javid C.Z. (2013) An investigation of effectiveness of simulation in developing oral skills: a case study. European Scientific Journal, no. 9 (32). Available at: http://eujournal.org/index.php/esj/article/ viewFile/2027/1939.

Jones 1982 - Jones K. (1982) Simulations in language teaching. Cambridge, England: Cambridge University Press, 122 p. DOI: http://doi.org/10.2307/327885.

Ke 2008 - Ke F. (2008) Computer games application within alternative classroom goal structures: cognitive, metacognitive, and affective evaluation. Educational Technology Research and Development, no. 56 (5/6), pp. 539-556. DOI: https://doi.org/10.1007/s11423-0089086-5.

Livingstone 1983 - Livingstone C. (1983) Role-play in language learning. Harlow: Longman, 94 p. Available at: https://perlinguam.journals.ac.za/pub/article/download/ $508 / 545$.

Ranalli 2008 - Ranalli J. (2008) Learning English with the sims: exploiting authentic computer simulation games for L2 learning. Computer Assisted Language Learning, no. 21 (5), pp. 441-455. Available at: https://lib.dr.iastate. edu/cgi/viewcontent.cgi?article $=1080 \&$ context=engl_pubs.

Rieber 2005 - Rieber L. (2005) Multimedia learning in games, simulations, and microworlds. In: Mayer R.E. (Ed.) The Cambridge handbook of multimedia learning. New York: Cambridge University Press, pp. 549-567. Available at: http://lrieber.coe.uga.edu/mayer2005/.

Ruben 1999 - Ruben B.D. (1999) Simulations, games, and experience-based learning: the quest for a new paradigm for teaching and learning. Simulation Gaming, no. 30 (4), pp. 498-505. DOI: http://doi. org/10.1177/104687819903000409.

Russell, Shepherd 2010 - Russell C. and Shepherd J. (2010) Online role-play environments for higher education. British Journal of Educational Technology, vol. 41, no. 6, pp. 992-1002. DOI: http://doi.org/10.1111/j.14678535.2009.01048.x.

Sutcliffe 2002 - Sutcliffe M. (2002) Simulations, games and role-play. In: Davies P. (Ed.) The handbook for economics lecturers. Available at: https://www.economicsnetwork. ac.uk/handbook/printable/games_v5.pdf.

Tompkins 1998 - Tompkins P.K. (1998) Role playing/ simulation. The Internet TESL Journal, no. 4 (8). Available at: http://iteslj.org/Techniques/Tompkins-RolePlaying.html. 


\section{Simulated Activities for RAW}

1. You're a publishing board whose task is to decide which papers to publish. Discuss your selection criteria. Study the abstracts and choose those than can be published in your journal. Think of the title for the journal and make sure all the articles fit well. Prepare some short feedback in writing for those whose abstracts are not chosen for publication.

2. Conduct questionnaires to find out what gadgets the students use most often (for group 1), whether they go out for sports and in what way (for group 2), and whether the students need social activities at the Business School (for group 3).

3. Interview students (for group 1), teachers (for group 2), and the university staff (for group 3) to find out whether they are satisfied with the university cafeteria. Think of the type of your interview (structured, semistructured, or open) and the questions you will ask. Share your findings with your group mates.

4. Most of you just participated in the so-called "Week of Science". Arrange a focus group discussion to find out whether it was a useful event. Choose a moderator who will handle the discussion and decide what questions you will ask. Think how to avoid possible mistakes.

5. The University has some money to spend and is considering what is the best way to allocate it. One of the ideas is to improve university sports facilities. Conduct a research to find out whether it is worth doing. Consider what data you need and what methods you are going to use. Collect, analyze your data, and present the results to your group mates.

6. Take turns to act as moderators during the presentations of your final papers. Think how to initiate discussion and provide constructive feedback from the audience.

Please answer the following questions.

\section{Student Questionnaire 1}

Appendix 2

1) How do you feel about writing in English? Put a check $\square$ next to as many boxes as you want.

I enjoy writing

So-so

Strongly dislike

Something else:

2) Do you think it's important for you to improve your writing? Why or why not?

$\square$ Very important $\square$ somewhat important $\square$ not important

3) What are your weak points in writing? Put a check $\square$ next to as many boxes as you want.

Organization and structure

Topic development

Argumentation

Grammar

Punctuation

Vocabulary

Something else:

4) Why do you think you have these problems? Put a check $\square$ next to as many boxes as you want.

Lack of knowledge

Lack of experience

Lack of desire to improve

Lack of understanding

Lack of time

Lack of effort

Lack of interest

Something else:

5) What do you think you should do to improve your writing? Put a check $\square$ next to as many boxes as you want. Write more

Edit your writing more thoroughly 
Analyze your writing

Learn the rules of syntax

Read more in English

Attend all the classes

Do all the teacher's assignments

Something else:

6) Other comments:

Thank you! $\odot$

Appendix 3

\section{Student Questionnaire 2}

Please answer the following questions.

1) What activities and forms of work are the most useful for you in mastering writing? Put a check $\square$ next to as many items as you want.

Exercises

Students' Group work

Writing Assignments (essays, papers, abstracts, etc.)

Collaborative learning (students with the teacher's assistance)

Peer review

Something else:

2) Please add any comments on how you'd like the writing course to be organized or taught.

Thank you! $\odot$

Appendix 4

Please answer the following questions.

\section{Student Questionnaire 3}

1) What activities and forms of work are the most useful for you in mastering writing? Put a check $\square$ next to as many items as you want.

Exercises

Simulated activities

Writing Assignments (essays, papers, etc.)

Collaborative learning (students with the teacher's assistance)

Peerreview

Something else:

2) What simulated activities did you like the most?

Selecting abstracts

Conducting questionnaires

Interviewing

Focus group discussion

Conducting full research

Moderating a mini-conference

3) Please provide comments on the writing course you've taken by completing the sentences:

The thing I liked best about it is

The thing I liked least is

The most difficult challenge was

Thank you! $\odot$ 